\title{
UPAYA MENINGKATKAN HASIL BELAJAR SISWA MELALUI MODEL PEMBELAJARAN KOOPERATIF THINK PAIR AND SHARE PADA MATA PELAJARAN MATEMATIKA
}

\section{THE EFFORTS TO IMPROVE LEARNING OUTCOMES THROUGH COOPERATIVE LEARNING MODEL THINK PAIR AND SHARE IN SUBJECT OF MATHEMATICS}

\author{
Pitriana1a, ZK Lathifah $^{2}$, dan H Makarim ${ }^{1}$ \\ 1 Program Studi Pendidikan Guru Sekolah Dasar, Fakultas Keguruan dan Ilmu Pendidikan, \\ Universitas Djuanda, Jl. Tol Ciawi No 1 Kotak Pos 35 16720, Bogor Indonesia \\ 2 Program Studi Manajemen Pendidikan Islam, Fakultas Keguruan dan Ilmu Pendidikan, \\ Universitas Djuanda, Jl. Tol Ciawi No 1 Kotak Pos 35 16720, Bogor Indonesia \\ a Korespondensi: Pitriana, Email: pitriana140@gmail.com \\ (Diterima: 20-09-2018; Ditelaah: 02-10-2018; Disetujui: 18-10-2018)
}

\begin{abstract}
The background of this research is the thoroughness of classical learning outcomes of students who have not achieved an indicator of research at least $75 \%$ of the number of students who reached the KKM mathematics set by the school at 65 . This research use approach Action Research (PTK), and implemented collaboratively and two cycles. This study aims to determine an effort to improve student learning outcomes through cooperative learning model Think Pair and share in the fourth grade mathematics courses at the State Elementary School Rancabakti Nanggung Bogor. The subjects were the fourth grade students of State Elementary School Rancabakti as many as 26 students consisting of 12 male students and 14 female students. Research was conducted in the second semester of the school year 2016/2017. The results showed that the average value of learning outcomes in Mathematics in the first cycle obtain an average value of 66.24 by the thoroughness of learning outcomes by $61.54 \%$, while the learning outcomes of the second cycle obtain an average value of 76.73 by the thoroughness of the results learning by $80.77 \%$. Similarly, the observation of the behavior of the students showed an increase in the student activity by obtaining the average value in the first cycle is 67.46 , while the second cycle obtain an average value of 81.29. This study concluded that cooperative learning model Think Pair and share to improve learning outcomes in Mathematics in grade IV in the State Primary School Rancabakti Nanggung Bogor. In addition this model can enhance the activity and thinking ability of students in the learning process.
\end{abstract}

Keywords: learning outcomes, mathematics think pair and share.

\begin{abstract}
ABSTRAK
Latar belakang masalah penelitian ini adalah ketuntasan hasil belajar siswa secara klasikal yang belum mencapai indikator penelitian minimal 75\% dari jumlah siswa yang mencapai KKM mata pelajaran Matematika yang telah ditetapkan oleh sekolah sebesar 65. Penelitian ini menggunakan pendekatan Penelitian Tindakan Kelas (PTK), dan dilaksanakan secara kolaboratif dan dua siklus. Penelitian ini bertujuan untuk mengetahui upaya meningkatkan hasil belajar siswa melalui model pembelajaran kooperatif think pair and share pada mata pelajaran matematika kelas IV di Sekolah Dasar Negeri Rancabakti Kecamatan Nanggung Kabupaten Bogor. Subjek penelitian ini adalah siswa kelas IV Sekolah Dasar Negeri Rancabakti sebanyak 26 siswa yang terdiri dari 12 siswa laki-laki dan 14 siswa perempuan.
\end{abstract}


Penelitian dilaksanakan pada semester genap tahun pelajaran 2016/2017. Hasil penelitian menunjukan bahwa nilai rata-rata hasil belajar mata pelajaran Matematika pada siklus pertama memperoleh nilai rata-rata 66,24 dengan ketuntasan hasil belajar sebesar 61,54\%, sedangkan hasil belajar siklus kedua memperoleh nilai rata-rata 76,73 dengan ketuntasan hasil belajar sebesar $80,77 \%$. Begitu pula dengan hasil observasi perilaku siswa menunjukan adanya peningkatan pada aktivitas siswa dengan memperoleh nilai rata-rata pada siklus pertama yaitu 67,46, sedangkan siklus kedua memperoleh nilai rata-rata sebesar 81,29. Penelitian ini berkesimpulan bahwa melalui model pembelajaran kooperatif think pair and share dapat meningkatkan hasil belajar mata pelajaran Matematika pada siswa kelas IV di Sekolah Dasar Negeri Rancabakti Kecamatan Nanggung Kabupaten Bogor. Selain itu model pembelajaran ini dapat meningkatkan keaktifan dan kemampuan berpikir siswa dalam proses pembelajaran.

Kata kunci: hasil belajar, matematika, model kooperatif think pair and share.

Pitriana, Lathifah, Z. K., \& Makarim, H. (2018). Upaya Meningkatkan Hasil Belajar Siswa Melalui Model Pembelajaran Kooperatif Think Pair and Share pada Mata Pelajaran Matematika. Didaktika Tauhidi: Jurnal Pendidikan Guru Sekolah Dasar, 5(2): 151-169.

\section{PENDAHULUAN}

Pada dasarnya Matematika merupakan ilmu yang abstrak dan deduktif, namun karena siswa Sekolah Dasar masih berada pada tahap operasional konkret yang belum dapat berpikir formal, sehingga pendekatan yang tepat dalam pembelajaran Matematika di sekolah dasar adalah pendekatan yang induktif. Maka dari itu, dalam setiap kesempatan, pembelajaran Matematika hendaknya dimulai dengan pengenalan masalah yang sesuai dengan situasi. Dengan mengajukan masalah kontekstual, peserta didik secara bertahap dibimbing untuk menguasai konsep Matematika melalui hasil belajar siswa yang mereka miliki.

Berdasarkan hasil observasi ketuntasan belajar siswa dalam implementasi kurikulum tingkat satuan pendidikan (KTSP) di Sekolah Dasar Negeri Rancabakti Kecamatan Nanggung Kabupaten Bogor, telah ditemukan bahwa pencapaian hasil belajar siswa pada mata pelajaran Matematika di kelas IV semester genap tahun pelajaran 2016/2017 melalui tes awal dengan materi pecahan ternyata hasil belajar siswa belum mencapai kriteria ketuntasan minimal (KKM) yang telah ditentukan oleh sekolah. Hal ini dapat diketahui dari jumlah 26 siswa di kelas IV, hanya terdapat 11 siswa (42,31\%) yang sudah tuntas hasil belajarnya, sementara sebanyak 15 siswa $(57,69 \%)$ belum mencapai ketuntasan yang diharapkan. Artinya ketuntasan hasil belajar siswa secara klasikal pada mata pelajaran Matematika di sekolah ini belum mencapai indikator keberhasilan penelitian minimal $75 \%$ dari jumlah siswa yang memperoleh KKM mata pelajaran Matematika sebesar 65.

Penyebab ketuntasan hasil belajar siswa dalam pembelajaran Matematika belum tercapai adalah karena matematika sering dianggap sebagai suatu mata pelajaran yang sulit (Gafoor \& Sarabi, 2015). Berdasarkan hasil pengamatan peneliti terhadap pelaksanaan pembelajaran Matematika yang dilakukan oleh guru di kelas, menunjukkan bahwa pembelajaran yang sedang berlangsung terlihat kurang efektif, karena model pembelajaran yang digunakan kurang menarik dan kurang melibatkan siswa saat kegiatan pembelajaran berlangsung, siswa juga terlihat pasif dan merasa jenuh, sehingga kondisi lingkungan kelas pun 
terasa kurang kondusif. Dengan demikian, guru sebagai tenaga pendidik harus mampu menerapkan model pembelajaran yang dapat meningkatkan hasil belajar siswa (Hirsh, 2013), sehingga pelaksanaan pembelajaran bisa berjalan secara efektif dan efisien. Untuk memecahkan masalah kurangnya kemampuan hasil belajar siswa, penulis menerapkan model pembelajaran Kooperatif Think Pair And Share (Shih \& Reynolds, 2015), karena model ini merupakan salah satu model pembelajaran kooperatif yang memberikan kesempatan lebih banyak kepada siswa untuk saling bertukar pendapat, saling membantu dan saling bekerjasama untuk menyelesaikan masalah yang dihadapinya (Lange, Costley, \& Han, 2016).

\section{MATERI DAN METODE}

Sesuai dengan fitrah manusia sebagai makhluk sosial yang saling ketergantungan dengan sesamanya, pembelajaran kooperatif sebagai miniatur hidup bermasyarakat mempunyai tujuan dan tanggung jawab bersama dalam menyelesaikan tugas kelompok (Salako, Eze, \& Adu, 2013). Pada dasarnya pembelajaran kooperatif atau cooperative learning mengandung pengertian sebagai suatu sikap atau perilaku bersama dalam bekerja atau membantu diantara sesama dalam kelompok, yang terdiri dari dua orang atau lebih dimana keberhasilan kerja sangat dipengaruhi oleh keterlibatan dari setiap anggota kelompok itu sendiri.

Cooperative learning berasal dari kata cooperative yang artinya mengerjakan sesuatu secara bersama-sama dengan saling membantu satu sama lainnya sebagai satu kelompok atau satu tim. Slavin yang dikutip oleh Isjoni mengemukakan "In cooperative learning methods, students work together in four member teams, to master material initially presented by the teacher". Artinya cooperative learning adalah suatu model pembelajaran dimana sistem belajar dan bekerja dalam kelompok-kelompok kecil yang berjumlah empat sampai enam orang secara kolaboratif sehingga dapat merangsang siswa lebih bergairah dalam belajar (Hutauruk, 2016). Model penelitian yang digunakan adalah Penelitian Tindakan Kelas (Class Action Reaserch). Pengertian Penelitian Tindakan adalah penelitian yang dilakukan oleh guru di kelas dengan menekankan pada penyempurnaan atau peningkatan proses dan praktis pembelajaran (Arikunto, 2012). Sedangkan menurut Asrori Penelitian Tindakan Kelas merupakan penyelidikan secara sistematis dengan tujuan menginformasikan praktik pembelajaran dalam situasi tertentu (Asrori, 2011). Tujuan dari penelitian ini yakni meningkatkan hasil belajar siswa melalui Model Pembelajaran Kooperatif Think Pair And Sharepada mata pelajaran Matematika kelas IV di Sekolah Dasar Negeri Rancabakti Kecamatan Nanggung Kabupaten Bogor semester genap tahun pelajaran 2016/2017. Penelitian dilaksanakan di Sekolah Dasar Negeri Rancabakti Kecamatan Nanggung Kabupaten Bogor yang berlokasi di Jalan Rancabakti RT 01/ RW 05 Kecamatan Nanggung Kabupaten Bogor. Penelitian dilaksanakan pada bulan Desember 2016Februari 2017, semester genap tahun pelajaran 2016/2017.

Penelitian ini dilakukan dengan menggunakan desain Penelitian Tindakan Kelas yang merujuk pada proses pelaksanaannya yang dikemukakan oleh Kemmis dan Taggart, Tahapan-tahapan dalam model Kemmis dan Taggart menggunakan sistem refleksi diri yang dimulai dengan perencanaan (Plan), 
tindakan dan pengamatan (Act and Observer), dan refleksi (Reflect) (Suwartono, 2014). Adapun gambar siklus penelitian tindakan kelas dapat dilihat pada Gambar 1.

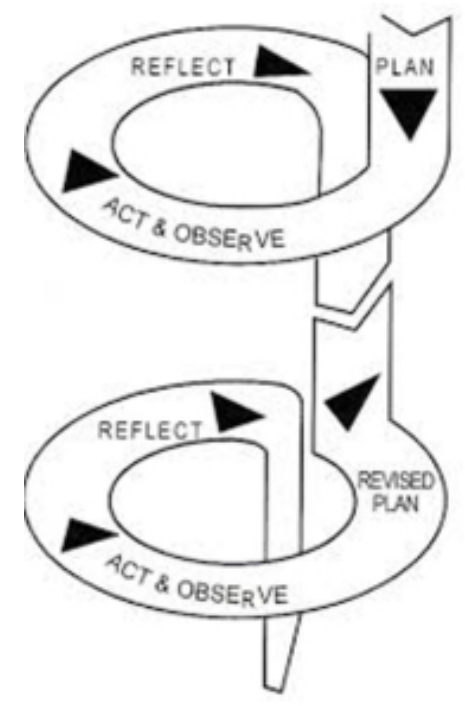

Gambar 1 Model Kemmis dan Taggart

\section{Planning (Perencanaan Tindakan)}

Kegiatan Planning dimulai dari proses identifikasi masalah yang akan diteliti. Setelah diuji kelayakan masalah yang akan diteliti kemudiandirencanakan tindakan selanjutnya untuk memperbaiki masalah yang terjadi. Hal yang perlu disiapkan dalam kegiatan ini adalah Rencana Pelaksanaan Pembelajaran (RPP), indikator keberhasilan yang akan dicapai dalam penelitian tindakan kelas, model pembelajaran yang dipilih, media yang digunakan, setting kelas dan juga jenis penilaian yang dipilih.

\section{Acting (Pelaksanaan Tindakan)}

Segala sesuatu yang telah direncanakan dalam Rencana Pelaksanaan Pembelajaran (RPP), selanjutnya peneliti melaksanakan tindakan reflektif (pembelajaran) dengan dibantu oleh tim kolaborator.

\section{Observing (Pengamatan)}

Observasi adalah kegiatan pengamatan selama berlangsungnya pelaksanaan tindakan (acting) dengan tujuan untuk melihat atau menilai sejauh mana efektivitas pelaksanaan tindakan kelas yang dilakukan, serta mengamati perubahan perilaku siswa yang nampak dalam proses pembelajaran.

\section{Reflecting (Refleksi)}

Refleksi adalah kegiatan mengulas secara kritis seluruh data yang ada. Pada tahap ini, guru dan kolaborator melihat indikator keberhasilan yang dicapai oleh peneliti dalam kualitas pelaksanaan pembelajaran di kelas, perubahan perilaku siswa yang terjadi saat pembelajaran berlangsung, dan ketuntasan hasil belajar siswa terhadap materi yang telah diajarkan. Selanjutnya berdasarkan hasil refleksi tersebut, guru bersama kolaborator menyimpulkan apakah tindakan yang dilakukan sudah dapat mencapai keberhasilan dari seluruh indikator yang ditentukan atau belum. Jika belum maka kekurangan-kekurangan yang terjadi selama siklus pertama direncanakan agar diperbaiki pada siklus berikutnya.

Prosedur penelitian tindakan kelas terdiri dari dua langkah secara garis besar yaitu prapenelitian dan penelitian tindakan kelas dalam bentuk siklus. Adapun kegiatannya sebagai berikut.

\section{Prapenelitian}

Prapenelitian merupakan refleksi awal sebelum penelitian tindakan dengan kegiatan sebagai berikut.

a. Menyusun form prapenelitian (instrumen pengumpulan data objektif sekolah).

b. Mengumpulkan data objektif sekolah dengan menggunakan form prapenelitian.

c. Melakukan analisis data objektif sekolah. 
d. Mengevaluasi hasil analisis data objektif sekolah dan digunakan untuk perencanaan tindakan kelas siklus I.

\section{Penelitian Tindakan Kelas}

\section{Siklus I}

Dalam melaksanakan kegiatan pada siklus I terdiri dari empat tahap, yaitu perencanaan tindakan, pelaksanaan tindakan, observasi dan refleksi. Adapun penjabaran deskripsi pertemuan siklus I sebagai berikut.

\section{1) Perencanaan Tindakan}

Pada tahap perencanaan tindakan dalam siklus I, peneliti dan observer berdiskusi untuk melakukan tindakan atau perbaikan dalam memecahkan permasalahan yang terjadi saat pembelajaran Matematika berlangsung. Berdasarkan hasil diskusi peneliti dan observer, maka disusunlah rencana pelaksanaan pembelajaran (RPP) untuk mata pelajaran Matematika dengan menerapkan model pembelajaran kooperatif think pair and share. Selain itu, peneliti juga menyusun perangkat pembelajaran yang akan dilaksanakan yang meliputi komponen sebagai berikut.

a) Silabus

Silabus mata pelajaran Matematika kelas IV semester genap tahun pelajaran 2016/2017 dengan standar kompetensi yaitu menggunakan pecahan dalam pemecahan masalah.

Program Semester

b) Program semester genap tahun pelajaran 2016/2017 kelas IV dengan kompetensi dasar yaitu menjelaskan arti pecahan dan urutannya.

c) Rencana Pelaksanaan Pembelajara $\left(\mathrm{RPP}_{1}\right)$
Rencana Pelaksanaan Pembelajaran $\left(\mathrm{RPP}_{1}\right)$ untuk mata pelajaran Matematika pada siklus I meliputi indikator:

(1) Membandingkan banyaknya dua benda yang berbeda.

(2) Menunjukkan pembilang dan penyebut pada pecahan.

(3) Menuliskan bentuk pecahan.

(4) Mengurutkan pecahan dari yang terkecil ke yang terbesar atau sebaliknya.

$\begin{aligned} & \text { Strategi } \\ & \text { diterapkan }\end{aligned}$ yaitu $\begin{array}{r}\text { dengang } \\ \text { pendekatan }\end{array}$
menggunakan
pembelajaran kontekstual, metode
pembelajaran ceramah bervariasi,
tanya jawab, kerja berpasangan,
diskusi kelompok dan penugasan,
serta model pembelajaran kooperatif
think pair and share.

d) Bahan Ajar (Materi Pembelajaran)

Materi pembelajaran yang dibelajarkan adalah tentang pecahan.

e) Lembar Kegiatan Siswa (LKS)

Bentuk lembar kegiatan siswa mata pelajaran Matematika dengan materi pembelajaran pecahan dengan berdiskusi secara kelompok.

f) Media dan Sumber Pembelajaran

Media pembelajaran yang digunakan adalah alat peraga pecahan, alat tulis (pensil, pulpen dan buku). Sumber pembelajaran yang digunakan adalah standar isi KTSP 2006 dan buku paket siswa kelas IV mata pelajaran Matematika.

2) Pelaksanaan Tindakan

Melaksanakan tindakan reflektif sesuai dengan Rencana Pelaksanaan Pembelajaran $\left(\mathrm{RPP}_{1}\right)$ yang telah 
dirancang. Peneliti melaksanakan pembelajaran diawali dengan kegiatan awal, kegiatan inti dan kegiatan akhir pembelajaran. Dalam kegiatan mengawali pembelajaran, terlebih dahulu peneliti mengkondisikan siswa ke dalam situasi belajar yang kondusif, kemudian melakukan apersepsi dan memberikan motivasi siswa. Kemudian peneliti menyampaikan cakupan materi yang akan dipelajari serta tujuan pembelajaran yang akan dicapai. Selanjutnya dalam kegiatan inti pembelajaran, peneliti melaksanakan kegiatan pembelajaran sebagai berikut.

\section{a) Eksplorasi}

(1) Guru mengajukan pertanyaan yang berkaitan dengan pecahan. Melaui kegiatan tersebut, siswa bersama guru menggunakan media pembelajaran pecahan.

(2) Guru menggali pengetahuan siswa dengan mengajak siswa untuk mengingat kembali tentang pecahan yang telah dipelajarinya.

\section{b) Elaborasi}

(1) Dengan disiplin, siswa mendengarkan penjelasan guru tentang materi pecahan.

(2) Siswa menanggapi penjelasan guru dengan menggunakan media/alat peraga yang ditunjukkan oleh guru.

(3) Siswa diberikan pertanyaan atau masalah berupa soal mengenai materi pecahan.

(4) Siswa diberikan kesempatan untuk memikirkan jawaban atas pertanyaan yang diberikan.

(5) Dengan disiplin, siswa diminta untuk berpasangan membentuk kelompok. Setiap kelompoknya terdiri dari 4 orang anggota berpasangan secara heterogen.

(6) Setiap kelompok mendiskusikan jawaban dari setiap pertanyaan tersebut dengan penuh ketekunan dan ketelitian.

(7) Dengan batas waktu yang ditentukan, setiap kelompok menukarkan lembar kegiatannya dengan kelompok lain.

(8) Dengan tanggungjawab, setiap kelompok mengemukakan hasil diskusinya dan kelompok lain menanggapinya.

\section{c) Konfirmasi}

(1) Guru memberikan penghargaan (reward) kepada setiap kelompok atas apa yang telah dikerjakan.

(2) Siswa diberikan kesempatan untuk menanyakan hal-hal yang belum dipahaminya.

Dalam mengakhiri kegiatan pembelajaran, siswa bersama guru menyimpulkan materi pembelajaran yang telah dipelajari, kemudian guru memberikan lembar soal evaluasi untuk mengetahui ketuntasan hasil belajar siswa terhadap materi pembelajaran yang telah diajarkan, dan selanjutnya guru melaksanakan refleksi serta tindak lanjut sebagai bentuk penguatan.

3) Observasi

Observasi dilakukan secara simultan pada saat pembelajaran berlangsung. kolaborator melakukan penilaian terhadap peneliti dalam kegiatan belajar mengajar di kelas dengan menggunakan instrumen penilaian kualitas pelaksanaan pembelajaran yang telah diberikan. Observer melakukan observasi terhadap aktivitas siswa selama pembelajaran 
berlangsung dengan menggunakan lembar observasi perbaikan perilaku siswa yang nampak.

4) Refleksi

Setelah kegiatan pembelajaran selesai, langkah berikutnya yaitu peneliti menganalisis ketiga jenis data yang terdiri dari data hasil kualitas pelaksanaan pembelajaran di kelas, hasil observasi perbaikan perilaku siswa dan ketuntasan hasil belajar siswa pada siklus I.

\section{Siklus II}

\section{Perencanaan}

Dalam perencanaan siklus II ini, perencanaan didasarkan terhadap hasil refleksi siklus I. Perencanaan meliputi rencana pelaksanaan pembelajaran, penyempurnaan model pembelajaan kooperatif think pair and share, dan mengoptimalkan proses pembelajaran. Perencanaan pada tahap ini dilakukan untuk hasil yang lebih baik.

Adapun langkah-langkah dalam siklus II ini sebagai berikut:

a. Identifikasi masalah pada siklus I, dan langkah perbaikan dalam siklus II.

b. Membuat Rencana Pelaksanaan Pembelajaran (RPP) yang memuat penerapan Model Pembelajaran Kooperatif Think Pair And Share dan Lembar Kerja Siswa (LKS).

c. Mempersiapkan alat peraga serta perlengkapan lain yang mendukung.

d. Menyusun lembar observasi bagi guru dan siswa.

e. Menyusun lembar pengamatan aktivitas bagi guru dan siswa.

f. Mengembangkan format evaluasi pembelajaran. g. Menetapkan indikator pencapaian dalam proses pembelajaran.

2. Tindakan

Pada tahap ini sebenarnya hampir sama dengan tindakan siklus I, yaitu pembelajaran Matematika dengan materi pokok pecahan dengan menerapkan Model Pembelajaran Kooperatif Think Pair And Share. Perbedaannya terdapat dalam proses pembelajaran dan instrumennya, pelaksanaan pada siklus II ini juga terbagi dalam dua pertemuan dengan materi yang sama.

\section{Observasi}

Dalam tahap observasi yang dilakukan adalah mengamati proses pembelajaran terhadap aktivitas siswa. Observasi diarahkan pada poin-poin dalam pedoman yang telah dipersiapkan sebelumnya

4. Refleksi

Tahapan ini merupakan tahapan untuk memproses data. Dalam tahapan ini dilakukan penilaian dan pengkajian data terhadap hasil evaluasi siklus II.

Dengan adanya perbaikan pembelajaran pada mata pelajaran Matematika di kelas IV Sekolah Dasar Negeri Rancabakti Kecamatan Nanggung Kabupaten Bogor dengan menerapkan Model Pembelajaran Kooperatif Think Pair And Share, maka indikator keberhasilan penelitian sebagai berikut.

a. Indikator Keberhasilan Kualitas proses pembelajaran minimal kategori baik.

b. Indikator keberhasilan hasil belajar siswa secara klasikal minimal 75\% dari jumlah 26 siswa yang mencapai KKM (65) yang ditetapkan oleh sekolah. 


\section{HASIL DAN PEMBAHASAN}

Penelitian tindakan kelas dilaksanakan secara dua siklus. Sebelum melaksanakan penelitian siklus I, terlebih dahulu peneliti melakukan tes awal terhadap siswa untuk mengetahui tingkat ketuntasan hasil belajar siswa sebelum tindakan reflektif (kegiatan pembelajaran) dimulai. Adapun deskripsi data hasil penelitian tes awal dan siklus I sebagai berikut:

\section{Data Hasil Tes Awal}

Tes awal dilakukan sebelum pelaksanaan pembelajaran siklus I dengan menggunakan soal siklus I yang valid. Peneliti

Tabel 1 Rekapitulasi data ketuntasan belajar hasil tes awal mata pelajaran matematika di kelas IV SDN Rancabakti

\begin{tabular}{llrrl}
\hline No & $\begin{array}{c}\text { Ketuntasan Hasil } \\
\text { Belajar }\end{array}$ & \multicolumn{1}{c}{ Frekuensi } & Persentase & \multicolumn{1}{c}{ Keterangan } \\
\hline 1 & Tuntas & 11 & $42.31 \%$ & KKM $=65$ \\
2 & Belum Tuntas & 15 & $57.69 \%$ & Jumlah Soal $=18$ \\
& Jumlah & 26 & $100 \%$ & Nilai Tertinggi $=83$ \\
& & & & Nilai Rata-rata $=22$ \\
& & & & \\
\hline
\end{tabular}

Berdasarkan Tabel 1, dapat diketahui bahwa dari jumlah 26 siswa di kelas IV Sekolah Dasar Negeri Rancabakti, terdapat 11 siswa (42,31\%) yang telah mencapai ketuntasan hasil belajar. Sedangkan siswa yang belum mencapai ketuntasan hasil belajar sebanyak 15 siswa $\quad(57,69 \%)$. Adapun nilai tertinggi yang diperoleh siswa adalah 83, sementara nilai terendah yang melaksanakan tes awal pada hari Senin tanggal 06 Februari 2017 di kelas IV Sekolah Dasar Negeri Rancabakti, dengan diikuti sebanyak 26 siswa. Tes awal dilakukan dengan tujuan untuk mengetahui keadaan awal kompetensi siswa terhadap materi pecahan dalam mata pelajaran Matematika yang akan diteliti. Berdasarkan data hasil pelaksanaan tes awal yang telah dianalisis, maka diperoleh ketuntasan belajar siswa hasil tes awal dapat dilihat pada Tabel 1.

Tabel 2 Distribusi frekuensi data ketuntasan belajar hasil tes awal mata pelajaran matematika di kelas IV Sekolah Dasar Negeri Rancabakti

\begin{tabular}{cccccc}
\hline No & Interval Nilai & Batas Kelas & Titik Tengah & $\mathrm{f}_{\text {absolut }}$ & $\mathrm{f}_{\text {relatif }}(\%)$ \\
\hline 1 & $22-32$ & $21,5-32,5$ & 27 & 2 & $7,70 \%$ \\
2 & $33-43$ & $32,5-43,5$ & 38 & 4 & $15,38 \%$ \\
3 & $44-54$ & $43,5-54,5$ & 49 & 5 & $19,23 \%$ \\
4 & $55-65$ & $54,5-65,5$ & 60 & 4 & $15,38 \%$ \\
5 & $66-76$ & $65,5-76,5$ & 71 & 9 & $34,61 \%$ \\
6 & $77-87$ & $76,5-87,5$ & 82 & 2 & $7,70 \%$ \\
& & Jumlah & & 26 & $100 \%$ \\
\hline
\end{tabular}


Berdasarkan Tabel 2, dapat diketahui bahwa dari jumlah 26 siswa terdapat 2 siswa $(7,70 \%)$ yang berada pada interval nilai $22-32$, selanjutnya sebanyak 4 siswa $(15,38 \%)$ berada pada interval nilai $33-43$, sedangkan sebanyak 5 siswa $(19,23 \%)$ berada pada interval nilai 44 - 54, kemudian sebanyak 4 siswa $(15,38 \%)$ berada pada interval nilai 55 - 65, sementara sebanyak 9 siswa $(34,61 \%)$ berada pada interval nilai 66 - 76, dan sebanyak 2 siswa $(7,70 \%)$ berada pada interval nilai 77 - 87. Dengan demikian dapat diketahui ketuntasan hasil belajar siswa pada tes awal yang sudah tuntas mencapai KKM mata pelajaran Matematika sebesar 65 adalah sebanyak 11 siswa (42,31\%). Sedangkan siswa yang belum mencapai ketuntasan sebanyak 15 siswa $(57,69 \%)$.

\section{Data Hasil Penelitian siklus I}

Penelitian siklus I dilaksanakan pada hari Selasa tanggal 07 februari 2017, yang mana peneliti melakukan tindakan reflektif (kegiatan pembelajaran) sesuai dengan rencana pelaksanaan pembelajaran yang telah dirancang sebelumnya dengan materi pembelajaran yang akan diajarkan yaitu tentang materi pecahan melalui model pembelajaran kooperatif think pair and share. Adapun deskripsi ketiga jenis data hasil penelitian siklus I yang telah dianalisis sebagai berikut.

\section{Data Hasil Penilaian Pelaksanaan Pembelajaran Siklus I}

Berdasarkan hasil pengamatan kedua kolaborator terhadap pelaksanaan pembelajaran yang dilakukan oleh peneliti, maka diperoleh data hasil penilaian kualitas pelaksanaan pembelajaran di kelas sebagai berikut:
Tabel 3 Rekapitulasi data hasil penilaian kualitas pelaksanaan pembelajaran siklus I

\begin{tabular}{lrl}
\hline \multicolumn{1}{c}{ Kolaborator } & \multicolumn{1}{c}{$\begin{array}{c}\text { Nilai } \\
\text { Akhir }\end{array}$} & Interpretasi \\
\hline 1 & 71,79 & Berkualitas \\
2 & 69,74 & Berkualitas \\
Jumlah & 141,54 & - \\
Rata-rata & 70,77 & Berkualitas \\
\hline
\end{tabular}

Tabel 3 menunjukan bahwa kualitas pelaksanaan pembelajaran pada siklus I, peneliti memperoleh nilai rata-rata sebesar 70,77 dengan interpretasi berkualitas. Hal ini dapat dilihat dari hasil penilaian yang diberikan oleh kolaborator 1 sebesar 71,79 dengan interpretasi berkualitas, dan hasil penilaian dari kolaborator 2 sebesar 69,74 dengan interpretasi berkualitas. Data Hasil Observasi Perbaikan Perilaku Siswa Siklus I

Selain kinerja guru yang dinilai, penilaian juga dilakukan oleh observer terhadap aktivitas atau perilaku siswa selama proses pembelajaran berlangsung. Hasil penilaian perilaku siswa secara kelompok saat pembelajaran Matematika dengan menerapkan model pembelajaran kooperatif think pair and share dapat dilihat pada tabel 4.

Berdasarkan Tabel 4, dapat dijelaskan secara rinci bahwa kelompok 1 memperoleh nilai rata sebesar 66,88 dengan interpretasi baik. Selanjutnya kelompok 2 memperoleh nilai rata-rata sebesar 69,83 dengan interpretasi baik, kemudian kelompok 3 memperoleh nilai rata-rata sebesar 66,25 dengan interpretasi baik. Sementara kelompok 4 dan 5 memperoleh nilai ratarata sama besar yakni 68,13 dengan interpretasi baik. Sedangkan kelompok 6 memperoleh nilai rata-rata sebesar 67,00 dengan interpretasi baik, dan kelompok 7 memperoleh nilai rata-rata sebesar 66,50 dengan interpretasi baik. Sehingga perolehan nilai rata-rata dari kelompok 1 
hingga kelompok 7 dari kedua observer adalah sebesar 67,46 dengan interpretasi baik. Untuk lebih memperjelas data hasil penilaian observasi perilaku siswa yang nampak secara kelompok, maka dapat digambarkan diagram histogram observasi perilaku siswa yang nampak pada siklus I seperti pada Gambar 2.

Tabel 4 Rekapitulasi data hasil observasi perilaku siswa yang nampak pada siklus I

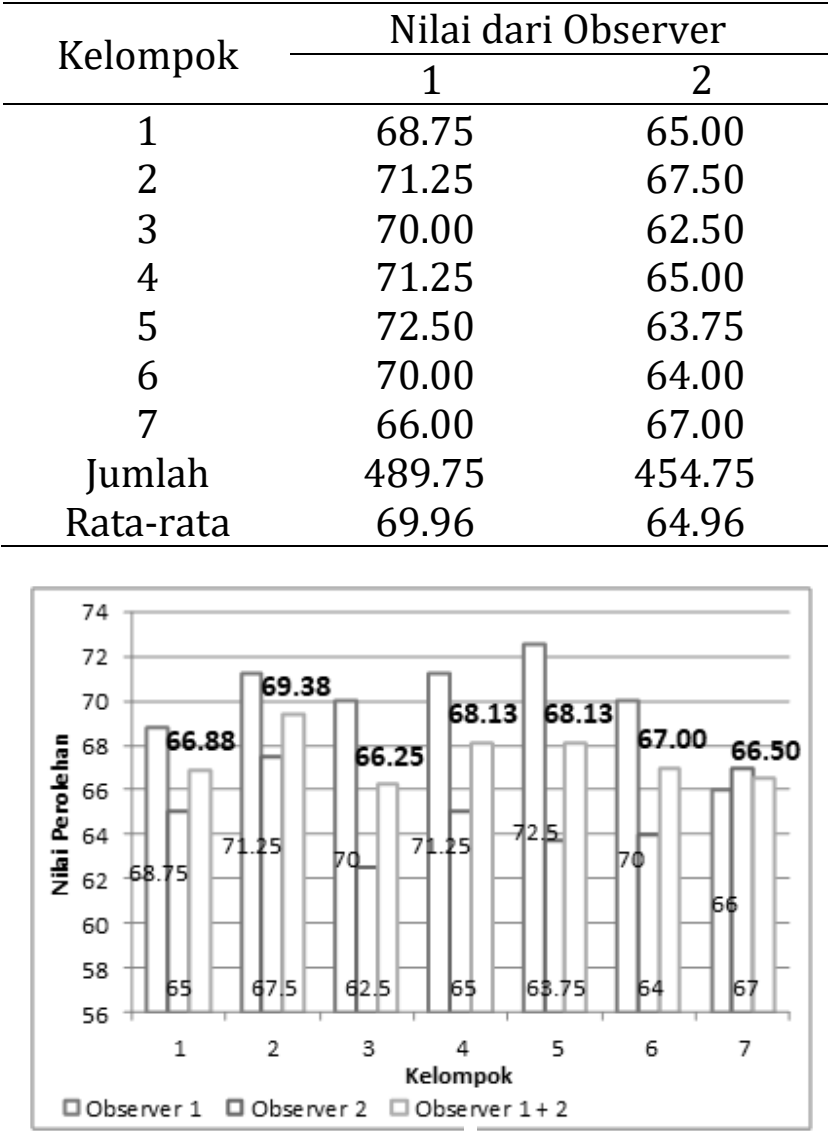

Gambar 2 Diagram hisfogram data hasil observasi perilaku siswa yang nampak pada siklus I

Hal ini menunjukan bahwa nilai rata-rata yang diperoleh setiap kelompok sudah tergolong dalam interpretasi baik. Namun demikian masih diperlukan adanya

\begin{tabular}{ccc} 
Subtotal & Rata-rata & Interpretasi \\
\hline 133.75 & 66.88 & Baik \\
138.75 & 69.38 & Baik \\
132.50 & 66.25 & Baik \\
136.25 & 68.13 & Baik \\
136.25 & 68.13 & Baik \\
134.00 & 67.00 & Baik \\
133.00 & 66.50 & Baik \\
944.50 & 472.25 & - \\
134.93 & 67.46 & Baik \\
perbaikan & dalam proses & pembelajaran \\
berikutnya & agar siswa terlihat lebih \\
berperan & aktif dalam & pembelajaran, \\
sehingga aktivitas atau perubahan perilaku \\
siswa pun semakin meningkat.
\end{tabular}

Data Ketuntasan Hasil Belajar Mata Pelajaran Matematika Siklus I di Kelas IV Sekolah Dasar Negeri Rancabakti Tahun Pelajaran 2016/2017

Penilaian selanjutnya yaitu ketuntasan hasil belajar siswa pada mata pelajaran Matematika tentang materi pecahan melalui penerapan model pembelajaran kooperatif think pair and share. Adapun pencapaian hasil belajar mata pelajaran Matematika pada siklus I dapat dilihat pada Tabel 5.

Tabel 5 Rekapitulasi data ketuntasan hasil belajar mata pelajaran Matematika Siklus I

\begin{tabular}{lrrrr}
\hline No & Ketuntasan Hasil Belajar & Frekuensi & Persentase & Keterangan \\
\hline 1 & Tuntas & 16 & $61.54 \%$ & KKM $=65$ \\
\hline 2 & Belum Tuntas & 10 & $38.46 \%$ & Jumlah Soal $=18$ \\
\hline \multicolumn{1}{c}{ Jumlah } & 26 & $100 \%$ & Nilai Tertinggi $=94$ \\
& & & & Nilai Terendah $=39$ \\
& & & Nilai Rata-rata $=66.24$ \\
\hline
\end{tabular}

Berdasarkan Tabel 5, dapat diketahui bahwa dari jumlah 26 siswa di kelas IV Sekolah Dasar Negeri Rancabakti yang mengikuti penilaian hasil belajar siklus I, terdapat 16 siswa $(61,54 \%)$ yang sudah mencapai ketuntasan hasil belajar. 
Sedangkan siswa yang belum mencapai ketuntasan hasil belajar sebanyak 10 siswa $(38,46 \%)$. Adapun nilai tertinggi yang diperoleh siswa adalah 94, sementara nilai terendah yang diperoleh adalah 39, dan untuk nilai rata-rata yang diperoleh pada siklus I ini adalah 66,24\%. Hal ini menunjukan bahwa ketuntasan hasil belajar siswa secara klasikal belum mencapai indikator keberhasilan penelitian minimal $75 \%$ dari jumlah siswa yang memperoleh KKM mata pelajaran Matematika sebesar 65.

Untuk memperjelas deskripsi data hasil belajar siklus I di atas, maka dapat digambarkan diagram histogram ketuntasan hasil belajar mata pelajaran Matematika pada siklus I seperti Gambar 3.

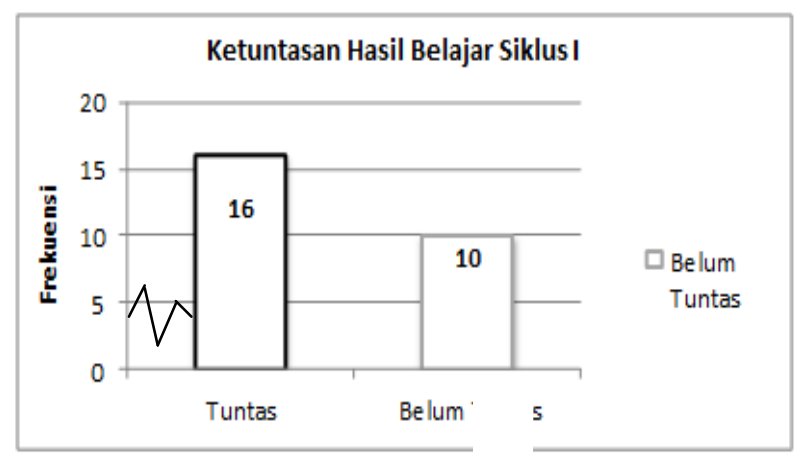

Gambar 3 Ketuntasan hasil belajar mata pelajaran matematika siklus I

Gambar 3 menunjukan bahwa ketuntasan hasil belajar siswa pada siklus I terdapat sebanyak 16 siswa yang sudah tuntas mencapai KKM mata pelajaran Matematika sebesar 65. Sedangkan sebanyak 10 siswa belum tuntas mencapai KKM tersebut. Untuk lebih jelasnya, akan dipaparkan pada tabel distribusi frekuensi dengan menggunakan aturan perhitungan Strugess sebagai berikut:

1) Range $(R)=$ Nilai tertinggi-Nilai terendah $=94-39=55$

2) Banyak kelas $(K)=1+3,3(\log 26)=1+$ $3,3(1,4149)=1+4,66917=5,66917$ dibulatkan menjadi 6
3) Panjang kelas (P) $=R: K=55: 6=9,17$ dibulatkan menjadi 10

Tabel 6 Distribusi frekuensi data ketuntasan hasil belajar mata pelajaran matematika siklus I

\begin{tabular}{|c|c|c|c|c|c|}
\hline No & $\begin{array}{c}\text { Interval } \\
\text { Nilai }\end{array}$ & $\begin{array}{l}\text { Batas } \\
\text { Kelas }\end{array}$ & $\begin{array}{c}\text { Titik } \\
\text { Tengah }\end{array}$ & $\mathrm{f}_{\mathrm{absolut}}$ & $\mathrm{f}_{\text {relatif }}(\%)$ \\
\hline 1 & $39-48$ & $\begin{array}{r}38,5- \\
48,5\end{array}$ & 43,5 & 2 & $7,70 \%$ \\
\hline 2 & $49-58$ & $\begin{array}{r}48,5- \\
58,5\end{array}$ & 53,5 & 5 & $19,23 \%$ \\
\hline 3 & $59-68$ & $\begin{array}{r}58,5- \\
68,5\end{array}$ & 63,5 & 9 & $34,61 \%$ \\
\hline 4 & $69-78$ & $\begin{array}{r}68,5- \\
78,5\end{array}$ & 73,5 & 6 & $23,08 \%$ \\
\hline 5 & $79-88$ & $\begin{array}{r}78,5- \\
88,5\end{array}$ & 83,5 & 1 & $3,84 \%$ \\
\hline 6 & $89-98$ & $\begin{array}{r}88,5- \\
98,5\end{array}$ & 93,5 & 3 & $11,54 \%$ \\
\hline \multicolumn{4}{|c|}{ Jumlah } & 26 & $100 \%$ \\
\hline
\end{tabular}

Berdasarkan Tabel 6, dapat diketahui bahwa dari jumlah 26 siswa terdapat 2 siswa $(7,70 \%)$ yang berada pada interval nilai 39 - 48, selanjutnya sebanyak 5 siswa $(19,23 \%)$ berada pada interval nilai $49-58$, sedangkan sebanyak 9 siswa $(34,61 \%)$ berada pada interval nilai 59 - 68, kemudian sebanyak 6 siswa $(23,08 \%)$ berada pada interval inai $69-78$, sementara sebanyak 1 siswa $(3,84 \%)$ berada pada interval nilai 79 - 88, dan sebanyak 3 siswa $(11,54 \%)$ berada pada interval nilai 89 - 98. Dengan demikian, dapat diketahui ketuntasan hasil belajar siswa pada siklus I yang sudah tuntas mencapai KKM mata pelajaran Matematika sebesar 65 adalah sebanyak 16 siswa $(61,54 \%)$. Sedangkan siswa yang belum mencapai ketuntasan sebanyak 10 siswa $(38,46 \%)$.

Pada Tabel 6, menunjukan bahwa distribusi tertinggi data hasil belajar siklus I berada pada batas kelas 58,5 - 68,5 yaitu sebanyak 9 siswa $(34,61 \%)$, sedangkan 
distribusi terendah berada pada batas kelas 78,5 - 88,5 yaitu sebanyak 1 siswa $(3,84 \%)$. Hal ini menunjukan bahwa sebagian besar siswa yang mengikuti penilaianhasil belajar siklus I belum mencapai kriteria ketuntasan minimal (KKM) mata pelajaran Matematika sebesar 65.

Tabel 7 Tingkat kesukaran butir soal siklus I

\begin{tabular}{llrrr}
\hline Interval & Interpretasi Jumlah Butir Soal Persentase & \multicolumn{2}{c}{ Nomor Butir Soal } \\
\hline $0,00-0,30$ & Sukar & 1 & $5.55 \%$ & 10 \\
$0,31-0,70$ & Sedang & 12 & $66.67 \%$ & $5,6,7,8,11,12,13,14,15,16,17,18$ \\
$0,71-1,00$ & Mudah & 5 & $27.78 \%$ & $1,2,3,4,9$ \\
Jumlah Keseluruhan & 18 & $100 \%$ & - \\
\hline
\end{tabular}

Berdasarkan Tabel 7, dapat diketahui bahwa dari jumlah 18 butir soal yang diberikan, terdapat 1 butir soal yang dikategorikan sukar dengan persentase 5,55\%, selanjutnya 12 butir soal dikategorikan sedang dengan persentase $66,67 \%$, dan sebanyak 5 butir soal dikategorikan mudah dengan persentase 27,78\%. (Analisis data ketuntasan hasil belajar dan tingkat kesukaran butir soal siklus I terdapat pada lampiran 5.4).

\section{Refleksi Penelitian Siklus I}

Setelah melakukan evaluasi terhadap hasil analisis data yang diperoleh dari tindakan reflektif (kegiatan pembelajaran) siklus I, selanjutnya peneliti bersama tim kolaborator melakukan diskusi untuk kegiatan refleksi mengenai hal-hal yang perlu diperbaiki pada siklus I dan diberikan solusi terbaik untuk siklus berikutnya. Adapun hal-hal yang direfleksikan atau direkomendasikan yaitu sebagai berikut:

\section{Hasil penilaian pelaksanaan pembelajaran di kelas}

Berdasarkan hasil evaluasi terhadap analisis dan interpretasi data hasil penilaian pelaksanaan pembelajaran siklus I, diketahui bahwa persiapan pelaksanaan pembelajaran belum maksimal, intonasi
Dengan melihat data ketuntasan hasil belajar siklus I, melalui 18 butir soal siklus I yang telah diberikan kepada siswa, maka dapat diketahui tingkat kesukaran butir soal siklus I seperti yang tertera dalam Tabel 7. suara kurang terdengar dengan jelas, media pembelajaran yang digunakan kurang menarik perhatian siswa, dan pengelolaan kelas yang kurang kondusif.

Untuk mengatasi masalah tersebut, maka direkomendasikan peneliti untuk memaksimalkan dalam persiapan pelaksanaan pembelajaran, mengoptimalkan suara secara lantang, menggunakan media pembelajaran yang lebih menarik (karya sendiri), dan mengkondisikan siswa dengan baik, sehingga dengan harapan proses pembelajaran berjalan dengan baik.

\section{Hasil observasi perilaku siswa yang nampak}

Hasil analisis dan interpretasi data observasi perubahan perilaku siswa yang nampak menunjukan bahwa masih ada siswa yang belum dapat bekerjasama dengan baik dalam kelompok, kurang aktif dan disiplin saat pembelajaran berlangsung. Hal ini disebabkan kurangnya pemberian motivasi dan penghargaan (reward) kepada siswa, kurang menarik perhatian siswa dengan media yang digunakan, serta mengkondisikan kelas yang belum maksimal.

Untuk memperbaiki hal tersebut, maka direkomendasikan agar peneliti 
menciptakan suasana belajar yang menyenangkan melalui pemberian motivasi, penghargaan dan penggunaan media pembelajaran yang lebih menarik perhatian siswa, sehingga siswa lebih bersemangat untuk menerima materi pembelajaran yang disampaikan. Selain itu peneliti juga perlu menjelaskan pentingnya bekerjasama dengan kelompok untuk saling bertukar pikiran/pendapat antar siswa dalam menyelesaikan persoalan atau masalah yang dihadapinya agar suasana belajar di kelas terlihat kondusif.

\section{Hasil Belajar Siswa}

Berdasarkan evaluasi ketuntasan hasil belajar siswa, diketahui bahwa pada siklus I masih terdapat 10 siswa yang belum mencapai KKM mata pelajaran Matematika sebesar 65, sementara ketuntasan hasil belajar siswa hanya 61,54\% dari jumlah 26 siswa yang mengikuti penilaian hasil belajar siklus I. Oleh karena itu, perlu direkomendasikan untuk melanjutkan penelitian tindakan pada siklus II karena secara klasikal ketuntasan hasil belajar siswa pada siklus I belum mencapai indikator keberhasilan penelitian sebesar $75 \%$.

\section{Data Hasil Penelitian Siklus II}

Penelitian siklus II dilaksanakan pada hari Selasa tanggal 09 Februari 2017 dengan materi pembelajaran yang akan diajarkan yaitu tentang garis bilangan pecahan dan mengurutkan pecahan dari yang kecil ke yang besar atau sebaliknya dengan menerapkan model pembelajaran kooperatif think pair and share. Adapun deskripsi ketiga jenis data hasil penelitian siklus I yang telah dianalisis, sebagai berikut.

\section{Data Hasil Penilaian Pelaksanaan Pembelajaran Siklus II}

Berdasarkan hasil pengamatan kedua kolaborator terhadap pelaksanaan pembelajaran yang dilakukan oleh peneliti, maka diperoleh data hasil penilaian kualitas pelaksanaan pembelajaran siklus II di kelas seperti yang tertera pada tabel 8 .

Tabel 8 Rekapitulasi data hasil penilaian kualitas pelaksanaan pembelajaran siklus II

\begin{tabular}{crc}
\hline Kolaborator Nilai Akhir & Interpretasi \\
\hline 1 & 88,72 & Sangat Berkualitas \\
2 & 87,18 Sangat Berkualitas \\
Jumlah & 175,90 & - \\
Rata-rata & 87,95 & Sangat Berkualitas \\
\hline
\end{tabular}

Berdasarkan tabel 8 dapat diketahui bahwa kualitas pelaksanaan pembelajaran pada siklus II mengalami peningkatan. Hal ini dapat dilihat dari perolehan nilai ratarata yang diberikan oleh kolaborator 1 sebesar 88,72, dan kolaborator 2 sebesar 87,18 dengan masing-masing interpretasi sangat berkualitas, sehingga diperoleh nilai rata-rata dari kedua kolaborator sebesar 87,95 dengan interpretasi sangat berkualitas.

\section{Data Hasil Observasi Perbaikan Perilaku Siswa Siklus II}

Penilaian juga dilakukan terhadap aktivitas atau perilaku siswa yang nampak selama proses pembelajaran berlangsung. Hasil penilaian perilaku siswa secara kelompok saat pembelajaran Matematika melalui model pembelajaran kooperatif think pair and share dapat dilihat pada tabel 9. Berdasarkan Tabel 9, dapat dijelaskan secara rinci bahwa kelompok 1 dan kelompok 4 memperoleh nilai rata sama besar yakni 78,13 dengan interpretasi baik. 
Tabel 9 Rekapitulasi data hasil observasi perilaku siswa yang nampak pada siklus II

\begin{tabular}{crrrrl}
\hline \multirow{2}{*}{ Kelompok } & \multicolumn{2}{c}{ Nilai dari Observer } & \multirow{2}{*}{ Subtotal } & \multirow{2}{*}{ Rata-rata } & \multicolumn{1}{c}{ Interpretasi } \\
\cline { 2 - 3 } & \multicolumn{1}{c}{2} & 70.00 & 156.25 & 78.13 Baik \\
1 & 86.25 & 78.75 & 166.25 & 83.13 Sangat Baik \\
3 & 87.50 & 86.25 & 175.00 & 87.50 Sangat Baik \\
4 & 88.75 & 75.00 & 156.25 & 78.13 Baik \\
5 & 81.25 & 83.75 & 165.00 & 82.50 Sangat Baik \\
6 & 81.25 & 80.00 & 166.25 & 83.13 Sangat Baik \\
7 & 86.25 & 79.00 & 153.00 & 76.50 Baik \\
Jumlah & 74.00 & 552.75 & 1138.00 & 569.00 - \\
Rata-rata & 585.25 & 78.96 & 162.57 & 81.29 Sangat Baik \\
\hline
\end{tabular}

Begitu pula dengan kelompok 2 dan kelompok 6 memperoleh nilai rata-rata sama besar yakni 83,13 dengan interpretasi sangat baik. Selanjutnya kelompok 3 memperoleh nilai rata-rata sebesar 87,50 dengan interpretasi sangat baik, sedangkan kelompok 5 memperoleh nilai rata-rata sebesar 82,50 dengan interpretasi sangat baik, dan kelompok 7 memperoleh nilai rata-rata sebesar 76,50 dengan interpretasi baik. Sehingga perolehan nilai rata-rata dari kelompok 1 hingga kelompok 7 dari kedua observer adalah sebesar 81,29 dengan interpretasi sangat baik.

Untuk mengetahui ketuntasan hasil belajar mata pelajaran Matematika tentang materi garis bilangan pecahan dan mengurutkan bilangan pecahan melalui model pembelajaran kooperatif think pair and sharepada siklus II dapat dilihat pada Tabel 10.

Tabel 10 Rekapitulasi data ketuntasan hasil belajar Mata Pelajaran Matematika Siklus II

\begin{tabular}{rlrrl}
\hline No & $\begin{array}{c}\text { Ketuntasan Hasil } \\
\text { Belajar }\end{array}$ & Frekuensi & Persentase & \multicolumn{1}{c}{ Keterangan } \\
\hline 1 & Tuntas & 21 & $80.77 \%$ & KKM $=65$ \\
\hline 2 & Belum Tuntas & 5 & $19.23 \%$ & Jumlah Soal $=20$ \\
& Jumlah & 26 & $100 \%$ & Nilai Tertinggi $=100$ \\
& & & Nilai Terendah $=60$ \\
& & & Nilai Rata-rata $=76.73$ \\
\hline
\end{tabular}

Tabel 10 menunjukan bahwa dari jumlah 26 siswa yang mengikuti penilaian hasil belajar siklus II, terdapat 21 siswa $(80,77 \%)$ yang telah mencapai ketuntasan hasil belajar. Sedangkan siswa yang belum mencapai ketuntasan hasil belajar sebanyak 5 siswa (19,23\%). Adapun nilai tertinggi yang diperoleh siswa adalah 100, sementara nilai terendah yang diperoleh adalah 60 , dan untuk nilai rata-rata yang diperoleh pada siklus II ini adalah 76,73. Hal ini menunjukan bahwa ketuntasan hasil belajar siswa secara klasikal telah mencapai indikator keberhasilan penelitian minimal $75 \%$ dari jumlah siswa yang memperoleh KKM mata pelajaran Matematika sebesar 65 .

\section{KESIMPULAN DAN IMPLIKASI}

\section{Kesimpulan}

Berdasarkan pembahasan hasil penelitian yang telah dilakukan, dapat ditarik simpulan bahwa upaya dalam meningkatkan hasil 
belajar siswa melalui model pembelajaran kooperatif think pair and share pada mata pelajaran matematikan kelas IV di Sedolah Dasar Negeri Rancabakti Kecamatan Nanggung Kabupaten Bogor semester genap tahun pelajaran.

\section{Implikasi}

Implikasi yang didapati sesudah penelitian selesai, yakni terdapat peningkatan ataupun bertambahnya hasil hasil belajar siswa melalui model pembelajaran kooperatif think pair and share.

\section{DAFTAR PUSTAKA}

Arikunto, S. (2012). Penelitian Tindakan Kelas. Jakarta: PT Bumi Aksara

Asrori, M. (2011). Penelitian Tindakan Kelas. Bandung: CV Wacana Prima.

Gafoor, K. A., \& Sarabi, M. (2015). Nature of Mathematics That Impacts Difficulties in Learning It: A Comparison of Student Perspectives on Learning School Subjects from Kerala. Online Submission.

Hirsh, S. (2013). The impact factor. The Learning Professional, 34(5), 10.

Hutauruk, S. S. (2016). The Effect of Cooperative Learning Model of Team Games Tournaments (TGT) Type On
Outcomes On Heat And Temperature Topic In Class X Semester II SMA Negeri 1 Sidikalang Ay 2015/2016.

Lange, C., Costley, J., \& Han, S. L. (2016). Informal cooperative learning in small groups: The effect of scaffolding on participation. Issues in Educational Research, 26(2), 260.

Salako, E., Eze, I., \& Adu, E. (2013). Effects of cooperative learning on junior secondary school students' knowledge and attitudes to multicultural education concepts in social studies. Education, 133(3), 303309.

Shih, Y.-C., \& Reynolds, B. L. (2015). Teaching adolescents EFL by integrating Think-Pair-Share and reading strategy instruction: A quasi-experimental study. RELC Journal, 46(3), 221-235.

Suwartono, S. (2014). Enhancing the pronunciation of English suprasegmental features through reflective learning method. TEFLIN Journal, 25(1), 80-93.

Tampubolon, S. (2014). Penelitian Tindakan Kelas. Jakarta: Erlangga. 